https://helda.helsinki.fi

Gone but not forgotten : the (re-)making of diaspora strategies

Chen, Yu-Wen

2015

Chen , Y-W , Racine, E \& Collins , N 2015 , ' Gone but not forgotten : the (re-)making of diaspora strategies ' , Asian Ethnicity , vol. 16 , no. 3 , pp. 371-379 .

http://hdl.handle.net/10138/328505

publishedVersion

Downloaded from Helda, University of Helsinki institutional repository.

This is an electronic reprint of the original article.

This reprint may differ from the original in pagination and typographic detail.

Please cite the original version. 


\section{Asian Ethnicity}

\section{Gone but not forgotten: the (re-)making of diaspora strategies}

\section{Yu-Wen Chen, Emilie Racine \& Neil Collins}

To cite this article: Yu-Wen Chen, Emilie Racine \& Neil Collins (2015) Gone but not forgotten: the (re-)making of diaspora strategies, Asian Ethnicity, 16:3, 371-379, DOI: 10.1080/14631369.2013.878210

To link to this article: https://doi.org/10.1080/14631369.2013.878210

曲 Published online: 31 Jul 2014.

Submit your article to this journal $\widetilde{T}$

Џ Article views: 475

Q View related articles ¿

View Crossmark data

4 Citing articles: 1 View citing articles 


\title{
Gone but not forgotten: the (re-)making of diaspora strategies
}

\author{
Yu-Wen Chen ${ }^{\mathrm{a} *}$, Emilie Racine ${ }^{\mathrm{a}}$ and Neil Collins ${ }^{\mathrm{b}}$ \\ ${ }^{a}$ Department of Government, University College Cork, Cork, Ireland; ${ }^{b}$ Graduate School of Public \\ Policy, Nazarbayev University, Astana, Kazakhstan
}

\begin{abstract}
This review article summarises the literature on the relations between states and their diaspora. Policy-makers are struggling to know how best to respond to and possibly harness the potential of kindred communities abroad. The article outlines a wide spectrum of policy initiatives and categorises them into three groups: economic, political and socio-cultural. Five economic, four political and two socio-cultural factors are discussed as are a wide variety of implementation strategies evident in different jurisdictions. Though the focus is on Asia, examples have been chosen from locations worldwide. Academically, the article identifies the empirical and conceptual deficiencies in studies on diaspora strategies.
\end{abstract}

Keywords: diaspora strategies; neoliberalism; economic factors; political factors; socio-cultural factors

\section{Introduction}

In this review article, we summarise academic discussions of the economic, political and socio-cultural conditions that have driven countries around the world to craft or modify their diaspora relationships and strategies. In recent years, there has been a significant intensification of interest in relations between states and their diaspora. This renewed interest is not solely academic and has coincided with the concerns of policy-makers, who are increasingly expected to understand and address issues arising from a world that is being transformed by migration. September 2006 marked an important point in the evolution of the research and policy with the scheduling of a United Nations HighLevel Dialogue on International Migration and Development (HLD). Diaspora engagement is now very much in vogue. ${ }^{1}$ The sending and receiving countries, as well as international entities such as the World Bank or the International Organisation for Migration (IOM), ${ }^{2}$ are all looking for the best way to respond to and possibly harness the potential of the world's diaspora communities.

Diaspora strategies are defined as policy initiatives aimed at fostering and managing relationships with a diaspora. ${ }^{3}$ They can vary from highly formalised and structured programmes to projects that are quite light in conception and application. In recent years, scholars have created a variety of classifications of diaspora strategies. Chander devised a straightforward classification: economic, political and cultural policy. ${ }^{4}$ Barry distinguishes between legal, economic and political instruments. ${ }^{5}$ Gamlen focusses on community building policies and mechanisms extending membership privileges and obligations. ${ }^{6}$

*Corresponding author. Email: yuwenjuliechen@yahoo.com 
Kalm uses the notion of governmentality as a theoretical framework to understand governmental approaches to emigration and diaspora strategies as a whole. ${ }^{7}$ The theory of governmentality, first propounded by French philosopher Michael Foucault and subsequently elaborated by Barbara Cruikshank and Nikolas Rose, essentially describes the strategic and calculated acts of governments to facilitate certain human conducts. ${ }^{8}$ Kalm argues that diaspora policies aim to promote a specific model of citizenship that is supposed to produce 'the mobile entrepreneurial and flexible emigrant citizen' on the one hand but holds the constant expectation that emigrants should continue to identify with and remain loyal to their home country on the other. ${ }^{9}$

It is widely acknowledged that diaspora policy has increasingly taken a neoliberal turn with migration being seen as a possible tool for development and the 'movement of people is understood as potentially conducive to development'. ${ }^{10}$ Larner notes that

In the policy documents of a myriad of international organisations, national governments and economic development agencies, diaspora strategies are now an integral part of a governmental imaginary in which entrepreneurial, globally networked, subjects create new possibilities for economic growth and in doing so contribute to the development of a knowledge based economy. ${ }^{11}$

Taking into consideration the limitations of using the notion of governmentality and the ideology of neoliberalism as tools for understanding diaspora strategies, it is crucial for governments and other policy networks to take into account the rights and requirements of the diaspora. This can be done by fostering a mutually beneficial relationship between a state and its diaspora. While sending countries are quick to call for their expatriate populations' economic and political contribution to the development of their country of origin, it is clear that most expatriates and their representative organisations expect this to be a two-way deal. Similarly, Lowell and Gerova point out that 'striking the right balance between a sending country's engagement in making use of its expatriate communities and the wishes and needs of such communities has yet to be found' ${ }^{12}$

In the following three sections, we provide a categorisation of the various factors that prompt states to foster different diaspora strategies. Although some factors are related to one another, we still categorise them into three broad groups: economic, political and socio-cultural. As we discuss these factors, we will give relevant empirical examples, and such cases are not limited to Asian countries and diaspora groups. It is expected that a global comparative perspective will help readers to understand the nature of the growing interest in diaspora policies academically and practically in various corners of the world. In the conclusion, we will address the current empirical and conceptual deficiencies in the field that should be taken into account in future endeavours.

\section{Economic factors}

There has been a growing awareness of the number of ways in which diaspora communities can contribute to home states' economic development. Here we discern five economic factors driving states to engage with their diaspora: foreign direct investment (FDI), access to foreign markets, creating business networks, encouraging return migration and source of foreign currency.

Regarding FDI and other resources, it is believed that expatriates hold crucial knowledge of the business environment of their home country. This leads their home governments to improve the conditions for diaspora's homeward investment. ${ }^{13}$ Vietnam's 
'renovation policy' in 1986 and other favourable policies created since the 2000s, for example, have aimed to entice overseas Vietnamese investment. ${ }^{14}$ Apart from Vietnam, China, India, Ireland, New Zealand, Latin America and the Caribbean countries also have initiatives to encourage their diaspora to contribute to the investment and development of their home states. ${ }^{15}$

The second economic incentive for governments is the possibility to access foreign markets via diaspora. Lowell and Gerova have highlighted 'nostalgic trade' as an important export market, where emigrants purchase goods from home in order to somehow feel close to their homeland. ${ }^{16}$ Gutiérrez maintains that one of the reasons why the Mexican government fosters a close relationship with its diaspora in the United States is that they constitute an 'extraordinary market for exports of Mexican products'. ${ }^{17}$ Corona beer, originally made in Mexico, is America's ninth best-selling beer and known all over the world. Initially the Mexican community in the United States used to buy Corona, and then it underwent a significant crossover from the diaspora market to the native-born US citizen market. $^{18}$

Cohen also emphasises the importance of this factor as he discusses the overseas market for exports created by the Chinese diaspora. ${ }^{19}$ Chinese migrant traders have not necessarily assimilated into their countries of residence and instead have remained loyal to potential business opportunities and profitable arrangements, by targeting the Chinese migrant market. Cohen notes that 'at the global level, the overseas Chinese represent a formidable economic network, exceeding in wealth the GNP's of all but the most powerful nation states'. ${ }^{20}$

The third economic factor that prompts states to develop diaspora strategy is the possibility to create and expand business networks via diaspora. Diasporas usually form networks that allow the circulation of knowledge, skills, capital and information. This then enables the easy transfer of business, manufacturing and finance opportunities. ${ }^{21}$

The circulation of knowledge might not be directly related to business. But various scholars have noted how China encourages its diaspora to transfer scientific knowledge back to China, with the aim of boosting the research and development (R\&D) environment at home. China is doing this in the hope to modernise itself and become more competitive in domestic and international markets. ${ }^{22}$

The fourth economic incentive is the possibility that the diaspora returning home would contribute to the economic performance of the home country. Return migration was the primary feature of the world's first diaspora strategies in the 1960s and some countries still place a heavy emphasis on the importance of return migration, particularly those that wish to move up the development ladder. For example, in 1993, Jamaica established a Charter for Long-Term Returning Residents, a programme that reduced costs for returnees. The Charter later became known as the Returning Resident Facilitation Unit, which became a government department in 1998. In 2002, a Minister for Diaspora Affairs was appointed, illustrating the significant evolution of Jamaica's Diaspora Policy. ${ }^{23}$

The last economic factor concerns remittances, which are often an invaluable source of income and foreign exchange earnings for a country. ${ }^{24}$ Ratha notes that remittances are less volatile than private capital flows and often rise during recessions, helping to stimulate vulnerable economies. $^{25}$

Gutiérrez has highlighted the importance of the Mexican diaspora in the United States as an important source of foreign currency through the remittances that migrant workers send to their families in Mexico. ${ }^{26}$ In the Cuban context, the Cuban-American community accounts for $68 \%$ of total remittances sent to Cuba. US Cubans send on average eight remittances a year, at an average of about US\$150 per remittance. 
As an incentive to such payments, various governments encourage a streamlined and cost-effective remittance process. ${ }^{27}$ For example, in 2006, India launched the Remittance Gateway system. This allows the Indian diaspora to send money to 14,500 locations in India at a far lower cost than commercial money wire companies.

While economic incentives are driving states to strengthen ties with diaspora, Lowell and Gerova argue that there is 'far too little known about the various mechanisms that may foster successful development in the wake of returning migrants ${ }^{28}$ and, therefore, many academics have been incorrectly assuming that return migration has a positive effect on the development of the home state.

For instance, using data from an original survey of 174 foreign-owned companies in Georgia, Graham found no evidence that diaspora-owned firms would demonstrate a specific set of 'socially responsible, pro-development' behaviours than other foreign companies in Georgia. ${ }^{29}$ Similarly, Chen shows that even China's hope to use diaspora to modernise the country are hindered by the unregulated, risk-averse and bureaucratic environment as well as the lack of experience in integrating R\&D and commercialisation in China. ${ }^{30}$

\section{Political factors}

Political factors can also prompt different states to implement certain strategies over others. Here we discern four political factors pertaining to expatriate voting, political lobbying, foreign policy objectives and the nature of a state's institutions in handling diaspora affairs.

First of all, the right to vote from abroad is a crucial factor that leads states to foster particular strategies with their diaspora. Expatriate voting allows migrants to assert membership of the political community and take part in efforts to produce policy changes in their home countries. By voting, migrants assert identification with their home country regardless of the caveat that migrants often have a voting agenda reflecting their own interests and experiences, which in turn can produce conflict. ${ }^{31}$

Electoral systems are increasingly allowing emigrants to vote from abroad with over 100 countries permitting expatriate voting. In 1988, for instance, when the Mexican government allowed its diaspora to vote, presidential candidate Cuauhtémoc Cárdenas, who had been expelled from the dominant Party of the Democratic Revolution, looked for support in the United States. ${ }^{32}$

Expatriate voting suggests that emigration 'does not disrupt the bonds of nationhood'. ${ }^{33}$ It is of particular interest to legal scholars, political scientists and others as it stands as an important symbol of the world's transnational community. This being said, it can also threaten host society's acceptance of the migrants for fear that immigrants represent a Trojan horse loyal to foreign people and states. ${ }^{34}$

In addition, Kalm suggests that some states hesitate to allow expatriates to vote as they essentially fail on two of the key elements that are required for participation in the democratic system. ${ }^{35}$ The first of these is sufficient knowledge of the political context and the second is behaving responsibly at the ballot. The absence of these two elements means 'extending voting rights is probably the most controversial among the diaspora strategies'. 36

Second, political lobby groups might also push states to foster diaspora strategies. For example, emigrants, either individually or as part of a collective lobbying group, may look to their home governments for support in their struggle for rights against discrimination in the labour market. 
The diaspora may also be expected by their home government to represent their country abroad and be good ambassadors. Øestergaard-Nielsen affirms that if migrants are expected to be good representatives and do some lobbying for their country of origin abroad, then they would often like some influence on the policies that they are expected to represent'. 37

The third political factor pertains to some states' interests in pursuing certain foreign policy strategies. For instance, Russia has used its diaspora to 'bolster the Russian Federation as a great power and to underscore Russia's special foreign policy role throughout the former Soviet Union'. ${ }^{38}$ The Turkish Republic of Northern Cyprus (TRNC) is another interesting case in point. As the TRNC is not internationally recognised as a sovereign state, it has exploited its diaspora's international networks to help overcome its international isolation. The international activism of Turkish Cypriots exhibits a kind of defensive transnationalisation that counterbalances the international actions of Greek Cypriots to de-legitimise TRNC. ${ }^{39}$

The last factor that affects how and why states to engage with their diaspora is the nature of government and history of institutions. For some countries, diaspora policy is a relatively new area of interest. This has meant that many agencies and institutions are relatively young. For example, until recently the Armenian government lacked the necessary resources needed to harness the potential of its diaspora. However, in 2000, a series of conferences between the government and the diaspora were organised in order to gain more knowledge on the state of diaspora affairs. The new Ministry for Diaspora Affairs was set up in 2008, and the 'Armenia 2020 Strategy' was devised. This strategy promotes inward investment through the Armenian Development Agency and the globalisation of indigenous firms through Armentech, an association of high-tech professionals of Armenian lineage. The establishment of a well-informed relationship in the early conferences has proved to work successfully for both willing diaspora groups and the home state. $^{40}$

\section{Socio-cultural factors}

We discern two socio-cultural factors that have been widely discussed to have affected states' formulation of diaspora policies: moral obligations and reputation of home country abroad as well as diaspora identity.

Often a country can be under pressure to engage with its diaspora for moral reasons or can be forced to do so by the diaspora's host country. ${ }^{41}$ The home country feels compelled to deal with its diaspora in this regard because its diaspora often serves as a country's permanent ambassadors abroad. Its diaspora's conduct in a foreign country will affect the home state's image abroad. More often than not, these moral reasons will be linked to the legal status of its citizens in host states and depends upon 'the extent to which the diaspora is creating a potential embarrassing situation because of "illegals" or "undocumented immigrants" in the country of adoption'. 42

Another socio-cultural factor contributing to how and why states engage with their diasporas is to promote a certain diasporic identity among its emigrants and a sense of still belonging to their homeland. Gutiérrez describes in depth the traditional relationship between Mexico and its diaspora in America in which the home state looked upon its emigrants as traitors and failures. He describes the Mexican government depicting its emigrants as 'pochos', meaning spoiled or over-ripe. He also discusses the characterisation of Mexican-Americans in Mexican cinema in which the characters typically lose their own identity and all connections with their homeland when attempting to assimilate into 
American society. Since the 1970 s, however, various governmental agencies of Mexico have been working to improve its relationship with the diaspora in America. ${ }^{43}$ Indeed, what was behind the Mexican government's motivation is not purely socio-cultural. There are also political and economic calculations involved as highlighted in previous sections. But the hope of fostering the diaspora's identification with its home is one of the driving forces.

\section{Conclusions}

Despite the re-emerging interests in diaspora strategies among governments, the administration process of such policies and programmes remains a critical concern. Some planned policy outcomes are being thwarted by ineffective implementation. In some countries, the implementation of a strategy is coordinated through a single or principal government agency, such as India's Ministry of Overseas Indian Affairs, Armenia's Ministry of Diaspora and Jamaica's Diaspora and Consular Affairs Department in the Ministry for Foreign Affairs and Trade. ${ }^{44}$ In 2010, the IOM carried out a specific review on government institutional structures in relation to diaspora engagement. The study found that there are 43 countries with either ministry-level or sub-ministry-level diaspora institutions. ${ }^{45}$ Elsewhere, there is no single agency that coordinates policy but a plethora of organisations are involved in handling diaspora affairs. Scotland and Ireland fall into this category. ${ }^{46}$

With regard to Asian countries and their diasporas in particular, there are empirical studies on India, China, Taiwan and, to a lesser extent, on Vietnam. But there is an obvious knowledge gap in what is going on in other Asian countries and their relationship with their diasporas.

Another caveat that has been raised by scholars working on diaspora in general is the neo-liberal approach to crafting diaspora strategies, making these policies elite-oriented and only targeted at the business and scientific communities. This is particularly apparent when gaining economic incentives is a home country's motive.

In a lot of the discourses presented by nation-states to foster diasporic relationships, loyalty and national identity are emphasised. For instance, Chinese diaspora are encouraged to 'serve the country' by solving the brain drain in China. ${ }^{47}$ While this kind of discourse would revive national identification among certain Chinese diaspora, it neglects those originating from China that may not be interested in this kind of 'nationalist' projects. The dynamic between the Chinese state and those who are not the targeted 'diaspora' is thus unspecified in current literature.

Take Tibetans and Uyghurs for example. China's relationship with these two diaspora groups has tended to be examined in a different category of academic literature. ${ }^{48}$ Confrontation is the predominant theme in their interactions. ${ }^{49}$ In terms of policy-making, there is a lack of discussion of China's diaspora strategies in handling relationships with Tibetans and Uyghurs abroad. Academically, there is also a black hole of unspecified concepts with regard to how such kind of relationship can be theorised in literature on diaspora strategies.

In a similar vein, Mani and Varadarajan point out that the Indian state's diaspora strategies do not concern diaspora who were expelled from India when Pakistan and Bangladesh, both primarily Muslim societies, sought independence. Hence, Hindu national identity is embedded in India's crafting of diasporic strategies, which is in contrast to the secular Indian state's claim to multiculturalism. ${ }^{50}$ There should be more 
efforts in filling the aforementioned empirical and conceptual deficiencies in the studies on diaspora strategies.

\section{Notes on contributors}

Yu-Wen Chen is Lecturer of Government at the University College Cork (UCC). Her research interest is in diaspora politics and ethnic mobilisation.

Author's postal address: Department of Government, University College Cork, Cork, Ireland.

Emilie Racine holds a MBS in International Public Policy and Diplomacy from the University College Cork (UCC).

Author's postal address: Department of Government, University College Cork, Cork, Ireland.

Neil Collins is Dean of the Graduate School of Public Policy, Nazarbayev University, Astana, Kazakhstan. His research interest is in public policy and management.

Author's postal address: Graduate School of Public Policy, Nazarbayev University, Astana, Kazakhstan.

\section{Notes}

1. Waldinger, "A Limited Engagement."

2. Ionescu, Engaging Diasporas as Development Partners.

3. Ancien, Boyle, and Kitchin, Exploring Diaspora Strategies.

4. Chander, "Homeward Bound."

5. Barry, "Home and Away."

6. Gamlen, Diaspora Engagement Policies.

7. Kalm, "Diaspora Strategies."

8. Foucault, "Governmentality"; Rose, Powers of Freedom; Cruikshank, The Will to Empower.

9. Kalm, "Diaspora Strategies," 393.

10. Ibid., 396.

11. Larner, "Expatriate Experts and Globalizing Governmentalities," 334.

12. Lowell and Gerova, Diasporas and Economic Development, 24.

13. Saxenian, Silicon Valley's New Immigrant Entrepreneurs, 54-55; Lucas, "International Migration Regimes."

14. Chan, "Hybrid Diaspora and Identity-Laundering."

15. Ho, "Claiming the Diaspora," 761; Zweig, Fung, and Han, "Redefining the Brain Drain."

16. Lowell and Gerova, Diasporas and Economic Development.

17. Gutiérrez, "Fostering Identities," 546.

18. See note 16 above.

19. Cohen, "Diasporas and the Nation State."

20. Ibid., 518-9.

21. Vertovec, The Political Importance of Diasporas; Lowell and Gerova, Diasporas and Economic Development, 21.

22. Ho, "Claiming the Diaspora," 761-2; Zweig, Fung, and Han, "Redefining the Brain Drain."

23. See note 3 above.

24. Farrant, MacDonald, and Sriskandarajah, Migration and Development, 14.

25. Ratha, "Workers Remittances."

26. Gutiérrez, "Fostering Identities."

27. See note 3 above.

28. Lowell and Gerova, Diasporas and Economic Development, 10.

29. Graham, "Diaspora-Owned Firms."

30. Ho, "Claiming the Diaspora," 761-2; Zweig, Fung, and Han, "Redefining the Brain Drain"; Chen, "The Limits of Brain Circulation."

31. Smith, Mexican New York.

32. Waldinger, "A Limited Engagement," 13.

33. Ibid., 7.

34. Øestergaard-Nielsen, "International Migration and Sending Countries."

35. See note 7 above. 
36. Ibid., 386.

37. Øestergaard-Nielsen, "International Migration and Sending Countries", 5.

38. King and Melvin, "Diaspora Politics," 134.

39. Chen, "A Comparative Qualitative Analysis," 20.

40. See note 3 above.

41. Laguerre, "State, Diaspora, and Transnational Politics," 635.

42. Ibid., 634 .

43. See note 26 above.

44. See note 3 above.

45. Agunias and Newland. Developing a Road Map.

46. Chen, "Un'analisi Comparativa delle Dimensioni Transnazionali."

47. Zweig, Fung and Han, "Redefining the Brain Drain."

48. Shih and Chen, Tibetan Studies in Comparative Perspective; Chen, The Uyghur Lobby.

49. Chen, The Uyghur Lobby.

50. Mani and Varadarajan, "The Largest Gathering of the Global Indian Family"; Ho, "Claiming the Diaspora," 764.

\section{References}

Agunias, Dovelyn Rannveig, and Kathleen Newland. Developing a Road Map for Engaging Diasporas in Development: A Handbook for Policymakers and Practitioners in Home and Host Countries. Washington, DC: International Organization for Migration \& Migration Policy Institute, 2012.

Ancien, Delphine, Mark Boyle, and Rob Kitchin. Exploring Diaspora Strategies: An International Comparison. Workshop report, June 2009. Accessed December 30, 2013. http://eprints.nuim.ie/ 2053/1/RK_Exploring_Diaspora_Strategies_International_Comparison.pdf

Barry, Kim. "Home and Away: The Construction of Citizenship in an Emigration Context." New York University Law Review 81, no. 1 (2006): 11-59.

Chan, Yuk Wah. "Hybrid Diaspora and Identity-Laundering: A Study of the Return Overseas Chinese Vietnamese in Vietnam." Asian Ethnicity 14, no. 4 (2013): 525-541.

Chander, Anupam. "Homeward Bound." New York University Law Review 81, no. 1 (2006): 60-89.

Chen, Yun-Chung. "The Limits of Brain Circulation: Chinese Returnees and Technological Development in Beijing." Pacific Affairs 81, no. 2 (2008): 195-215.

Chen, Yu-Wen. "A Comparative Qualitative Analysis of the International Activism of Ethnopolitical Groups in Europe." Ethnopolitics 11, no. 1 (2012): 43-65.

Chen, Yu-Wen. "Un'analisi Comparativa delle Dimensioni Transnazionali dei Movimenti Nazionalisti Scozzese e Gallese.” Partecipazione e Conflitto 2 (2010): 39-61.

Chen, Yu-Wen. The Uyghur Lobby: Global Networks, Coalitions and Strategies of the World Uyghur Congress. London: Routledge, 2014.

Cohen, Robin. "Diasporas and the Nation State from Victims to Challengers." International Affairs 72, no. 3 (1996): 507-520.

Cruikshank, Barbara. The Will to Empower: Democratic Citizens and Other Subjects. Ithaca, NY: Cornell University Press, 1999.

Farrant, Macha, Anna MacDonald, and Dhananjayan Sriskandarajah. Migration and Development: Opportunities and Challenges for Policymakers. Geneva: International Organization for Migration, 2006. Accessed December 30, 2013. http://www.iom.int/jahia/webdav/site/myjahiasite/shared/shared/mainsite/published_docs/serial_publications/MRS\%2022\%20IPPR.pdf

Foucault, Michel. "Governmentality." In The Foucault Effect: Studies in Governmentality, edited by Graham Burchell, Colin Gordon and Peter Miller, 87-104. Chicago: University of Chicago Press, 1991.

Gamlen, Alan. Creating and Destroying Diaspora Strategies. International Migration Institute Working Paper 31. Oxford: University of Oxford, 2011.

Gamlen, Alan. Diaspora Engagement Policies: What Are They, and What Kinds of States Use Them? COMPAS Working Papers 32. Oxford: Centre on Migration, Policy and Society, 2006.

Graham, Benjamin A. T. "Diaspora-Owned Firms and Social Responsibility." Review of International Political Economy 21, no. 2 (2014): 432-466. doi:10.1080/09692290.2012.747103.

Gutiérrez, Carlos Gonzalez. "Fostering Identities: Mexico's Relations with Its Diaspora." The Journal of American History 86, no. 2 (1999): 545-567. 
Ho, Elaine Lynn-Ee. "Claiming the Diaspora: Elite Mobility, Sennding State Strategies and the Spatialities of Citizenship." Progress in Human Geography 35, no. 6 (2011): 757-772.

Ionescu, Dina. Engaging Diasporas as Development Partners for Home and Destination Countries: Challenges for Policy Makers. Geneva: International Organization for Migration, 2006.

Kalm, Sara. "Diaspora Strategies as Technologies of Citizenship." Global Society 27, no. 3 (2013): 379-397.

King, Charles and Neil J. Melvin. "Diaspora Politics: Ethnic Linkages, Foreign Policy, and Security in Eurasia." International Security 24, no. 3 (1999): 108-138.

Laguerre, Michael S. "State, Diaspora, and Transnational Politics: Haiti Reconceptualised." Journal of International Studies 28, no. 3 (1999): 631-651.

Larner, Wendy. "Expatriate Experts and Globalizing Governmentalities: The New Zealand Diaspora Strategy." Transactions of the Institute of British Geographers 32 (2007): 331-345.

Lowell, B. Lindsay and S. G. Gerova. Diasporas and Economic Development: State of Knowledge. Washington, DC: World Bank, 2004.

Lucas, R. E. B. International Migration Regimes and Economic Development. Report prepared for the Expert Group on Development Issues (EGDI) in the Swedish Ministry of Foreign Affairs, 2005.

Mani, Bakirathi and Latha Varadarajan. "The Largest Gathering of the Global Indian Family: Neoliberalism, Nationalism and Diaspora at Pravasi Bharatiya Divas." Diaspora: A Journal of Transnational Studies 14, no. 1 (2008): 45-74.

Øestergaard-Nielsen, Eva. "International Migration and Sending Countries: Key Issues and Themes." In International Migration and Sending Countries: Perceptions, Policies and Transnational Relations, edited by Eva Øestergaard-Nielsen, 3-29. Basingstoke: Palgrave, 2003.

Ratha, Dilip. Workers Remittances: An Important and Stable Source of External Finance. Global Development Finance Report 2003. Washington, DC: World Bank, 2003.

Rose, Nikolas. Powers of Freedom: Reframing Political Thought. Cambridge: Cambridge University Press, 1999.

Saxenian, AnnaLee. Silicon Valley's New Immigrant Entrepreneurs. San Francisco: Public Policy Institute of California, 1999.

Shih, Chih-Yu, and Yu-Wen Chen. Tibetan Studies in Comparative Perspective. London: Routledge, 2012.

Smith, Robert. Mexican New York: Transnational Lives of New Immigrants. Berkeley: University of California Press, 2006.

Vertovec, Stephen. The Political Importance of Diasporas. Migration Information Source, 2005. Accessed December 30, 2013. http://www.migrationinformation.org/Feature/display.cfm?ID=313

Waldinger, Roger D. "A Limited Engagement: Mexico and its Diaspora." The Selected Works of Roger D Waldinger, 2009. Accessed December 30, 2013. http://works.bepress.com/roger_waldinger $/ 38 /$

Zweig, David, Chung Siu Fung, and Donglin Han. "Redefining the Brain Drain: China's 'Diaspora Option'.” Science Technology, and Society 13, no. 1 (2008): 1-33. 